*Pós-doutorando da Universidade Estadual do Norte do Paraná (UENP). Doutor em Direito do Estado pela Pontifícia Universidade Católica de São Paulo (PUCSP). Professor de Graduação e Pós-graduação (Mestrado) em Direito da Universidade Metodista de Piracicaba (UNIMEP). Professor de Graduação em Direito do Centro Universitário Adventista de São Paulo (UNASP). Promotor de Justiça do Ministério Público do Estado de São Paulo Aposentado. Advogado.

**Mestrando em Direito pela Universidade Metodista de Piracicaba (UNIMEP). Especialista em Ciências Criminais pela Pontifícia Universidade Católica de Minas Gerais. Assessor jurídico do Centro Universitário Adventista de São Paulo. Advogado.E-mail: fernandocerqueira.adv@gmail. com

\section{Interrogatório Policial: Natureza Jurídica à Luz do Modelo Constitucional Democrático BRASILEIRO}

\author{
Police Interrogation: Juridical Nature in Regarding \\ the Brazilian Democratic Constitutional Model
}

\section{José Antonio Remedio* Fernando Cerqueira Cardoso**}

Como citar: REMEDIO, José Antonio; CARDOSO, Fernando Cerqueira. Interrogatório policial: Natureza jurídica à luz do modelo constitucional democrático brasileiro. Revista do Direito Público, Londrina, v. 16, n. 1, p. 48-69, abr. 2021. DOI: 10.5433/24157-108104-1.2021v16n1p. 48. ISSN: 1980-511X

Resumo: A pesquisa tem por objeto analisar a natureza jurídica do interrogatório policial à luz do modelo constitucional democrático brasileiro. Vige no ordenamento jurídico nacional o princípio da supremacia da Constituição. Isto significa que todos os demais diplomas legislativos devem obediência aos preceitos constitucionais. Ocorre que o princípio da supremacia da Constituição nem sempre é observado em relação ao interrogatório realizado em sede policial, o que acarreta sensíveis prejuízos aos direitos fundamentais do investigado na esfera penal. $\mathrm{Na}$ doutrina, sem uniformidade de pensamento, o interrogatório ora possui natureza jurídica probatória, ora natureza defensiva em favor do investigado, e ora natureza mista, dotada ao mesmo tempo dos elementos informativos probatório e defensivo. Todavia, são bastante variadas as implicações práticas ao investigado criminalmente, decorrentes da adoção das diferentes espécies de natureza jurídica adotadas pela doutrina em relação ao interrogatório policial. O método utilizado é o hipotéticodedutivo, com base na legislação, doutrina e jurisprudência. Conclui que, com base no modelo constitucional democrático brasileiro, em especial aos princípios constitucionais da ampla defesa e do contraditório, o interrogatório policial possui natureza jurídica de defesa, e não natureza probatória ou mista, possibilitando, assim, efetiva proteção dos direitos fundamentais da pessoa investigada criminalmente.

Palavras-chave: Inquérito policial. Interrogatório policial. Interrogatório policial no modelo democrático. Modelo 
constitucional democrático. Natureza jurídica do interrogatório policial.

Abstract: This research explores the legal nature of police questioning in light of the Brazilian democratic constitutional model. In this context, the principle of the supremacy of the Constitution prevails in the national legal system. This means that all other laws must obey constitutional precepts. However, the principle of the supremacy of the Constitution is not always observed in relation to questioning in police headquarters, which causes significant damage to the fundamental rights of the accused in criminal proceedings. In academia, there is much debate as there is no uniformity of thought. Moreover, the interrogation sometimes has a legal evidential nature, sometimes a defensive nature in favor of the investigated, and sometimes a mixed nature, with both evidential and defensive informative elements. Moreover, the practical implications for the criminally investigated are quite varied, resulting from the adoption of any of the previous mentioned types in relation to police questioning. The hypothetical-deductive method is used, based on legislation, doctrines, and jurisprudence. This paper concludes that, based on the Brazilian democratic constitutional model, especially the constitutional principles of ample defense and adversarial proceedings, police questioning has the legal nature of defense, and not evidential or mixed nature, thus enabling effective protection of the fundamental rights of the criminally investigated person.

Keywords: Police investigation; Police interrogation; Police interrogation in the democratic model; Democratic constitutional model; Juridical nature of the police interrogation. 


\section{INTRODUÇÃO}

A doutrina controverte-se sobre a natureza jurídica do interrogatório policial e dos efeitos decorrentes do entendimento adotado, inclusive em razão dos riscos à proteção dos direitos fundamentais do investigado criminalmente.

A pesquisa objetiva analisar a natureza jurídica do interrogatório policial brasileiro, perscrutando a essência teórica do interrogatório policial, de modo a verificar se a redação infraconstitucional, ou ainda a construção doutrinária ordinária, apresentam-se como antítipos do tipo do constitucional ou desta proposta destoam.

Justifica-se a pesquisa em face do constante embate teórico, com efeitos práticos, que se lança sobre a temática. Alguns posicionam o interrogatório como elemento informativo probatório, outros como elemento defensivo, e alguns outros, a partir de entendimento moderado, como elemento informativo misto, com viés probatório e defensivo.

Entretanto, é necessário examinar a conexão do entendimento com o suporte teórico que o sustenta, ou se o referencial teórico eleito parte do centro catalisador de todo o ordenamento jurídico pátrio, ou seja, a Constituição Federal de 1988.

Identificada a natureza do instituto, propõe-se, em linha utilitarista, verificar os desdobramentos práticos de tal entendimento a partir de algumas balizas utilizadas para a construção do ato, tais como: a assistência de advogado durante a realização do interrogatório; a entrevista pessoal e reservada do indiciado com o seu advogado; o direito ao silêncio; a condição que paira sobre o artigo 155 do Código Processo Penal; os efeitos das alterações promovidas pela Lei n. 13.245/16, que alterou o Estatuto da Ordem dos Advogados do Brasil, na materialização do ato.

Ao transcrever paralelo entre a realidade presente e a eventual discrepância com o modelo democrático proposto pela Constituição Federal, pretende-se fazer incidir maior clareza sobre o instituto, de modo que este cumpra seu mister, tanto no deslinde da persecução penal estritamente considerada, quanto no fortalecimento do principal fundamento sob o qual está assentada a República Brasileira, ou seja, a dignidade da pessoa humana.

O método utilizado é o hipotético dedutivo, com base na legislação, doutrina e jurisprudência.

No tocante à estrutura, a pesquisa inicia-se com a análise da natureza jurídica do interrogatório policial, abordando as questões relacionadas ao interrogatório como elemento informativo probatório, defensivo e misto. A seguir trata das implicações práticas decorrentes relacionadas à natureza jurídica do interrogatório policial, enfocando a obrigatoriedade de assistência por advogado, o direito ao silêncio do investigado e a incoerência entre a natureza jurídica do interrogatório e a convicção do magistrado a partir do disposto no art. 155 do Código de Processo Penal, e as recentes alterações do Estatuto da Ordem dos Advogados do Brasil como reflexo do modelo democrático constitucional nacional.

Tem-se, como hipótese, que o interrogatório policial possui natureza jurídica de elemento defensivo, à luz do modelo constitucional democrático nacional, o que possibilita o respeito aos 
princípios constitucionais que regem a matéria e a preservação dos direitos fundamentais do investigado criminalmente.

\section{A NATUREZA JURÍDICA DO INTERROGATÓRIO POLICIAL BRASILEIRO}

A questão afeta à natureza jurídica do interrogatório policial não é pacífica na doutrina, havendo a respeito diversos entendimentos, alguns entendendo-a como elemento informativo probatório, outros como elemento defensivo, e alguns outros como elemento misto, ou seja, informativo probatório e defensivo.

\subsection{O Interrogatório policial como elemento informativo probatório}

Nos termos do artigo 196 do Código de Processo Penal, o interrogatório pode ocorrer a todo tempo, seja qual for o ponto da persecução criminal. Entretanto, o diploma processual penal aponta, de maneira específica, apenas duas ocasiões em que o ato deve ser realizado: o primeiro em sede administrativa, perante a autoridade policial; o segundo em sede judicial, no findar da audiência de instrução, em presença da autoridade judiciária.

Ocorre que, embora cada ato seja realizado em momento distinto da marcha persecutória, e em igual medida busquem finalidades diversas, o procedimento adotado para o interrogatório policial e judicial, por força da Constituição Federal (art. 5, LV e LXIV) e do Código de Processo Penal - CPP (art. $\left.6^{\circ}, \mathrm{V}\right)$, dispõe de estreito vínculo ritual.

$\mathrm{O}$ inciso $\mathrm{V}$ do art. $6^{\circ}$ do $\mathrm{CPP}$ estatui que a autoridade policial, logo que tiver conhecimento da prática da infração penal, deverá ouvir o indiciado, com observância, no que for aplicável, do disposto no Capítulo III do Título, do Livro I, do Código de Processo Penal.

A expressão "no que for aplicável", constante do inciso V do art. $6^{\circ}$ do $\mathrm{CPP}$, permite afirmar que as disposições concernentes ao interrogatório perante a autoridade judiciária devem alcançar e conferir diretrizes ao procedimento adotado pela autoridade policial.

Tal correlação, oriunda da própria construção legislativa e aperfeiçoada com o advento das Leis ns. 10.792/2003, 11.690/2008, 11.719/2008 e 11.900/2009 seria capaz, ao menos em tese, de conferir algum alento àqueles que militam em favor das bases constitucionais. Porém, a linha interpretativa convencionalmente abraçada, que rotula o sistema processual penal como acusatório, acaba por macular toda a cadeia de atos empreendidos no transcorrer da persecução penal.

Os ataques ao instituto, sobretudo do interrogatório judicial, por gozar de previsão legal expressa e direta, consistem em classificá-lo como meio de prova, ou ainda, como instituto processual de natureza mista. Tal postura, por via reflexa, acaba por posicionar o interrogatório policial como elemento informativo probatório ou elemento informativo misto.

Neste primeiro viés, isto é, o interrogatório como elemento informativo probatório, com 
tracejado declaradamente inquisitorial, o investigado é ontologicamente desfigurado, vez que sua condição de sujeito é subtraída para conferir espaço à ultrajante posição de objeto, inversão de axiomas esta combatida por Marta Saad (2006, p. 6), ao afirmar que "a integridade do sistema constitucional depende do valor que se atribua à liberdade individual e à valorização do acusado - ainda que informalmente acusado, no inquérito policial - como sujeito de direitos e não mero objeto de investigação".

Afinal, compactuar com persecução que aflija e reduza o indiciado à condição de pecador, predisposto à confissão do seu pecado como última instância da verdade, representa, na lição de Jacinto Nelson de Miranda Coutinho (2009, p. 105), retrocesso que alcança os Tribunais da Santa Inquisição:

Excluídas as partes, no processo inquisitório o réu vira um pecador, logo, detentor de uma "verdade" a ser extraída. Mais importante, aparentemente, que o próprio crime, torna-se ele objeto de investigação. É sobre si que recaem as atenções, os esforços do inquisidor. Detentor da "verdade", dela deve dar conta. Eis a razão por que a tortura ganhou a importância que ganhou, e a confissão virou regina probationum.

Com efeito, certo é que deste cariz inquisitorial se aproxima o interrogatório como elemento informativo probatório, porquanto não apenas se afasta das bases epistemológicas democráticas originalmente propostas pela Constituição Federal, mas nem mesmo observa, de forma pura, o sistema acusatório convencionalmente aceito. O que, no entender de Aury Lopes Júnior (2013, p. 5), inibe o conhecimento progressivo da vontade popular constitucionalmente firmada, ou seja, a nova ordem democrática "exige um rompimento, pois cria um verdadeiro obstáculo epistemológico. Daí o valor do critério de democraticidade de Cunha Martins, pois dizer 'democrático' é dizer o contrário de 'inquisitivo', é dizer o contrário de 'misto' e é dizer mais do que acusatório".

Quando o inquérito policial ou o interrogatório policial é utilizado como instrumento para a construção de provas que ensejarão, já em fase judicial, a fundamentação do édito condenatório, tanto o primeiro, enquanto instituto jurídico, quanto o segundo, como proposta procedimental, renegam sua finalidade, para, em modelo velado, suplantar o sistema democrático ou mesmo o sistema acusatório, e materializar o sistema inquisitivo. Conforme se observa da precisa preleção de Aury Lopes Júnior (2000, p. 85):

[...] a eficácia probatória dos atos dainstrução preliminar deve serendoprocedimental, servindo apenas para justificar o processo ou não-processo e como fundamento das decisões interlocutórias que o juiz tenha de tomar no curso da instrução preliminar. [...] não se atribui a fase pré-processual o poder de aquisição da prova, somente deve recolher elementos úteis à determinação do fato e da autoria, em grau de probabilidade, para justificar a ação penal. [...] não existe repetição, mas sim produção, porque prova valorável na sentença só existe quando praticada em juízo ou por meio do respectivo procedimento judicial de produção antecipada. 
Nessa toada, à luz do modelo democrático proposto pela Constituição Federal, que zela pelo adequado posicionamento do Estado-juiz e dos atores processuais no transcorrer da persecução criminal, bem como vindica proteção ao contraditório e à ampla defesa, necessário se faz firmar para que serve o interrogatório policial, ou ainda, quaisquer dos elementos colhidos perante a autoridade policial: a) justificar o processo ou o não-processo; b) fundamentar as decisões interlocutórias que, de forma excepcional, tenha o juiz que tomar no curso da instrução preliminar.

Assim, não se confere ao interrogatório policial ou ao inquérito policial o poder para aquisição de prova. Tal proceder é inconteste desvirtuamento da instrução preliminar constitucionalizada, que projeta para o interrogatório policial o mero recolhimento de elementos úteis para observação do fato e de sua suposta autoria, embora sempre em grau de probabilidade que eventualmente justifique a ação penal.

Para aqueles que insistem em vislumbrar o interrogatório policial como elemento informativo probatório que, de forma maquiada, suprime a condição de sujeito do indiciado e o reduz à posição de objeto, há uma verdade peremptória a ser descoberta e extraída do interrogado. Uma justificativa, portanto, para o desatino epistemológico, que garantiria então, posteriormente, em sede judicial, a devida reprimenda. Tal alento, entretanto, na observação de Jacinto Nelson de Miranda Coutinho (2009, p. 108-109), não se revela legítimo, uma vez que considera a linguagem numa perspectiva limitada:

[...] não são poucos os que sustentam a necessidade - e por que não a concreta possibilidade? - de se entender e discutir tudo a partir da "descoberta da Verdade", por evidente que ignorando os giros produzidos pela linguagem. Para tanto se passar - como parece elementar - há, sem dúvida, uma crença na real possibilidade de se obter a Verdade pelo conhecimento do objeto e, assim, aposta-se nos postulados da Filosofia da Consciência como o genial caminho da descoberta.

É nesse afã de obter a suposta verdade real, que o interrogado é feito objeto para obtenção de prova, diga-se, com aproveitamento não apenas para a fase inquisitiva, o que já seria reprovável, mas com elasticidade suficiente para munir o cotejo judicial.

Nessa quadra, o sistema democrático constitucional é violado e, por consequência, a natureza institucional do interrogatório policial, intrinsecamente defensiva, como se verá adiante, é maculada, de modo a fraudar a identidade e finalidade do ato desenvolvido em sede policial.

\section{$1.2 \mathrm{O}$ interrogatório policial como elemento informativo defensivo}

Cediço é o entendimento de que o inquérito policial, na condição de procedimento administrativo, em regra não abre margem à vindicação do contraditório e da ampla defesa como princípios balizadores de sua materialização. Entretanto, a partir de análise mais acurada, é possível verificar que o dogma popularizado e consagrado por considerável parcela da comunidade jurídica 
não se coaduna com os termos da Constituição Federal.

Sobre a temática, em apontamento revelador, Aury Lopes Júnior (2003a, p. 391) esmiúça os termos do inciso LV, artigo $5^{\circ}$ do Diploma Constitucional, trazendo à tona o real sentido e alcance da proposta do Poder Constituinte Originário, sustentando que o inquérito policial constitui expressão do exercício do direito de defesa:

O direito de defesa é um direito réplica, que nasce com a agressão que representa para o sujeito passivo a existência de uma imputação ou ser objeto de diligências e vigilância policial. Nesta valoração reside um dos maiores erros de numerosa doutrina brasileira que advoga pela inaplicabilidade do art. $5^{\circ}, \mathrm{LV}$, da Constituição ao inquérito policial, argumentando que não existem "acusados" nessa fase, eis que não foi oferecida denúncia ou queixa. Ora, não é preciso maior capacidade de abstração para verificar que qualquer notícia-crime que impute um fato aparentemente delitivo a uma pessoa determinada, constitui uma imputação, no sentido jurídico de agressão, capaz de gerar no plano processual uma resistência. Foi isso que o legislador constitucional quis dizer com "acusados em geral" (notese bem, o texto constitucional não fala simplesmente em "acusados", o que daria abrigo a uma leitura mais formalista, mas sim "acusados em geral", o que sem dúvida é muito mais amplo e protecionista).

Dessa forma, resta equivocado o entendimento de que o inquérito policial gozaria de maior eficácia com a alienação do contraditório e da ampla defesa produzidos pelo defensor do indiciado. Afinal, considerando-se que o que se busca é a verdade, então esta deve ser decorrência do contraditório.

Nessa trilha, em que a defesa em sede administrativa assume contornos incontestáveis e as partes postulantes são identificadas como colaboradoras na construção do composto investigativo, que ensejará ou não a abertura da ação penal, mister se faz indicar o momento em que a defesa será convocada para atuar no procedimento. Marta Saad (2006, p. 6), em específico tratamento da temática, esclarece:

Para efetivação desse direito, previsto constitucionalmente, contudo, é preciso ir além, porque rotineiramente não se concede ao informalmente acusado a assistência de defensor dativo; na maioria das vezes, não se lhe explicitam os direitos constitucionais e, pior, muitos dos meios de prova, colhidos no curso do inquérito, sem qualquer participação da defesa, são utilizados para sustentar futuras sentenças condenatórias. [...] O momento inicial para o exercício do direito de defesa deveria ser, assim, o indiciamento, porque encerra juízo de probabilidade quanto à autoria. [...] Por isso, o suspeito, que não foi indiciado formalmente, mas que teve restringidos direitos fundamentais, deve poder exercer sua defesa, até mesmo para que não seja depois indiciado. Para se assegurar o exercício da defesa, é imprescindível que se dê ciência ao acusado da imputação e de todo o conteúdo dos atos de instrução constantes do inquérito; além disso, é preciso garantir a assistência de advogado e a faculdade de exercício do direito ao silêncio. 
É preciso acentuar que o exercício da defesa perante a autoridade policial deve ocorrer antes mesmo do indiciamento, visto que também objetiva justamente evitá-lo. A estratégia defensiva nesse pré-ato ocorre em duplo viés, ou seja, tanto por intermédio da defesa técnica que combate e suscita os termos tendentes à rejeição do indiciamento, quanto a partir da autodefesa ofertada pelo próprio suspeito caso assim prefira proceder.

A autodefesa, neste momento, é o próprio interrogatório policial, que tanto pela sua posição na dinâmica procedimental, quanto por sua finalidade constitucional, só pode ser identificado como elemento informativo defensivo. Qualquer traço probatório que macule ou desvirtue o discurso do sujeito interrogado deve ser rejeitado, visto não se coadunar com sua natureza estritamente defensiva.

Nestes termos, não se pode aceitar que o indiciamento do suspeito ocorra apenas no findar do inquérito, quando a autoridade policial então elabora o relatório final do quanto até ali investigado. Antes que o relatório seja redigido, e, por consequência, se proceda a análise quanto ao eventual indiciamento, o suspeito ou indiciado em potencial deve ser interrogado, ainda que já tenha se manifestado anteriormente nos autos do inquérito policial.

Aury Lopes Júnior e Roberta Coelho Klein (2013, p. 5), em expressa indignação com a sequência dos atos convencionalmente adotados pela Polícia Judiciária, mesmo após o advento da Lei ${ }^{\circ}$ 12.830/2013, declaram:

[...] o indiciamento realizado no final do inquérito policial, junto do relatório elaborado pela autoridade policial, fere direitos do indiciado, pois não mais the permite o exercício do direito de defesa com vistas à reversão da situação. O certo seria que o sujeito passivo fosse previamente ouvido para só então ser decidido pelo indiciamento ou não, devendo a autoridade policial informar, claramente, em caso de indiciamento, permitindo o exercício do direito de defesa antes da conclusão do inquérito.

Portanto, "o processo penal deve passar pelo filtro constitucional e democratizar-se através do fortalecimento do sujeito passivo. O indivíduo submetido ao processo penal passa a ser valorizado juridicamente (democracia = fortalecimento do indivíduo)" (LOPES JÚNIOR, 2003a, p. 382).

Tal linha interpretativa, que observa a persecução criminal à luz do sistema democrático constitucional, só pode atribuir ao interrogatório, seja o ocorrido perante a autoridade judiciária, seja o verificado em sede administrativa, a natureza de meio de defesa e elemento informativo defensivo.

Entretanto, é preciso ressaltar que o contraditório e a ampla defesa exercidos em sede policial são distintos de sua postulação ocorrida em juízo. Trata-se de espécie do gênero defesa, mas não se confunde com a defesa desenvolvida em sentido estrito, vez que o procedimento administrativo não abre margem à estruturação da dialética processual. De acordo com Lopes Júnior (2003a, p. 386): 
É importante destacar que quando falamos em "contraditório" na fase pré-processual estamos fazendo alusão ao seu primeiro momento, da informação. Isto porque, em sentido estrito, não pode existir contraditório no inquérito porque não existe uma relação jurídico-processual, não está presente a estrutura dialética que caracteriza o processo. Não havendo o exercício de uma pretensão acusatória, não pode existir a resistência. Sem embargo, esse direito à informação - importante faceta do contraditório adquire relevância na medida em que será através dele que será exercida a defesa.

Dessa forma, à luz da Constituição Federal, certo é que o inquérito policial deve conferir ao indiciado ou suspeito as garantias do contraditório e da ampla defesa. A consagração deste dogma, numa perspectiva constitucional democrática, repercute em todos os atos que compõem a persecução criminal, de modo que o instituto jurídico do interrogatório, inclusive o ocorrido perante a autoridade policial, deve contar com as elementares oriundas desta sistemática, ainda que não o seja no estrito modelo judicial caracterizado pela dialética processual.

\section{$1.3 \mathrm{O}$ interrogatório policial como elemento informativo misto}

Ainda em paralelo ao interrogatório judicial, o interrogatório policial é entendido por considerável parcela da doutrina pátria como elemento informativo misto, ou seja, tanto serve à composição do conjunto probatório preliminar, quanto à exposição defensiva do interrogado.

Contudo, essa proposta não deve prevalecer, vez que não só afronta a pureza do sistema democrático constitucional, como também suplanta o sistema acusatório a que pretende enaltecer, espraiando de forma velada o ranço inquisitório por toda persecução criminal.

Frente à encenação jurídica, Jacinto Nelson de Miranda Coutinho (2009, p. 110) denuncia:

O dito processo misto, com o hálito do qual Napoleão tocou o mundo a partir da Europa continental mostrou-se, desde sempre, uma fraude à democracia processual. No fundo, o sistema napoleônico nada mais era - e é, para quem o adota - um Sistema Misto, ou seja, um Sistema Inquisitorial mesclado com elementos provenientes do Sistema Acusatório, sobretudo partes, acusação separada formalmente do órgão julgador e debates orais. Por ele - e para ficar em poucos exemplos - nazistas, fascistas, soviéticos e todos os regimes totalitários chamaram de "democráticos" seus sistemas processuais penais, em geral tratandoos como "Sistemas Acusatórios".

Supõem os defensores do sistema misto que as vertentes inquisitiva e acusatória podem trafegar juntas, ficando isentas de quaisquer sequelas. Entendem que, do mesmo modo que o princípio inquisitivo catalisa as características e funções do sistema inquisitivo, e o princípio acusatório assim o faz no sistema acusatório, um princípio unificador de natureza mista emergiria 
da amálgama de ambos. Nada mais equivocado. Consoante Jacinto Nelson de Miranda Coutinho (2009, p. 109):

O problema é que é o fim do sistema - como referido -, que resignifica o princípio unificador e ele, como é elementar, ganha um colorido diferente nos dois sistemas conhecidos: o princípio unificador será inquisitivo se o sistema for inquisitório; e será dispositivo se o sistema for acusatório. Como ideia única, não comporta divisão e, deste modo, não se pode ter um princípio misto e, de consequência, um sistema misto.

É deste entrevero epistemológico que surge o sistema misto, construção doutrinária desvirtuada e destoante da proposta democrática constitucional. Seus tentáculos, oriundos de junção inquisitória e acusatória, comprometem toda persecução penal, inclusive alcançando o interrogatório realizado em sede policial.

A partir de suas bases, o interrogado, ontologicamente ferido em sua natureza, é reduzido à condição de objeto apto à produção de provas ao arrepio do contraditório e da ampla defesa, vez que em eventual momento posterior a prova seria reproduzida.

Ora, primeiro que o interrogatório policial é instituto de natureza estritamente defensiva, como antes afirmado, não detendo qualquer finalidade probatória. Segundo que, ainda que de tal ato pudesse ser extraído algum elemento tendente a prejudicar o indiciado ou o suspeito, este se faria na linha que deslinda todo o inquérito policial, isto é, para a mera justificação do processo ou do não-processo.

Entretanto, em um sistema misto, que propõe a mescla dos atributos inquisitórios, acusatórios e defensivos, mesmo o interrogatório policial, sob a gerência probatória do magistrado, pode se tornar elemento apto a sustentar o édito condenatório judicial, ainda que de forma velada, nos problemáticos termos do artigo 155 do Código de Processo Penal. Também por esta razão, os defensores do sistema democrático constitucional repudiam o apensamento do inquérito policial aos autos do processo penal.

A partir desta sistemática híbrida, o contraditório e a ampla defesa garantidos ao indiciado ou suspeito pelo sistema democrático constitucional, são postergados para o trâmite processual, ocasião em que a alta carga de provas, já construídas e valoradas em ambiente inapropriado e sem o devido acompanhamento da defesa técnica, lançam o acusado em posição ainda mais distante do eventual édito absolutório, ou mesmo, de sua condição de presumida inocência.

Para aqueles que insistem em mesclar os sistemas inquisitório e acusatório, em explícita afronta ao contraditório e à ampla defesa garantidos perante a autoridade policial por força da Constituição Federal, não custa lembrar, a partir do apontamento de Ruchester Marreiros Barbosa (2016, p. 31), que:

Acusado em geral não é aquele denunciado formalmente pelo órgão de acusação. Caso contrário, deveríamos suprimir as garantias individuais nos processos administrativos disciplinares, na primeira fase, ou sindicâncias administrativas, 
pois nestes não há "litigantes em processo judicial ou administrativo". Há processo administrativo, mas não há litigantes propriamente ditos, e mesmo assim se admite defesa como construção doutrinária e jurisprudencial, porque neles há uma imputação de infração administrativa.

O sistema misto, nesta linha, nada mais é do que velada barganha jurídico-política. Tão vexatório é o sistema inquisitório, que para manter as aparências e maquiar o seu verdadeiro aspecto, atribuíram-lhe título e forma híbridos.

\section{IMPLICAÇÕES PRÁTICAS DECORRENTES DA NATUREZA JURÍDICA DO INTERROGATÓRIO POLICIAL}

Entende-se por natureza jurídica a condição intrínseca de um ato, fato ou instituto que compõe o ordenamento jurídico. A partir da natureza de cada uma destas variáveis, são catalisadas e traçadas as características e funções das elementares que estruturam o sistema proposto.

Todavia, a sistemática material e processual não é delineada de forma desconexa e pontual. Seus contornos devem ser balizados pela norma superior de cada território e nação soberana, ou seja, precisa coadunar-se com a proposta constitucional que organizou o Estado, elencou funções oriundas do poder único estatal e firmou os direitos e garantias fundamentais. A natureza dos sistemas e dos institutos nele inseridos é parte de um composto mais abrangente, correspondente à Lei Fundamental do Estado.

No caso brasileiro, em que se adotou de forma expressa o Estado Democrático de Direito (artigo $1^{\circ}$, caput, da Constituição Federal) (BRASIL, 1988), cumpre sustentar sua influência na construção da sistemática ramificada por todo o ordenamento jurídico, assumindo, no caso da processualística penal, a feição convencionalmente intitulada de democrática constitucional.

Tal linha interpretativa, não obstante os reveses promovidos pelo retrógrado procedimento inquisitivo ou mesmo pelo insuficiente sistema acusatório, deve prevalecer, conferindo o adequado tom prático à materialização dos atos e institutos que compõem a dinâmica do direito material e instrumental, inclusive do interrogatório policial, elemento informativo intrinsecamente defensivo, consoante os termos do Estado Democrático de Direito e do sistema democrático constitucional que dele emana.

\subsection{Sistemas processuais e a variabilidade substancial do interrogatório policial}

A sistemática adotada para execução do trâmite processual ou da persecução criminal afetará de forma direta e intrínseca a construção de cada instituto que compõe a cadeia de atos processuais.

Sendo assim, partindo do pressuposto de que a Constituição Federal conferiu contornos 
à sistemática processual penal, mister se faz evidenciar as implicações práticas decorrentes da variante epistemológica eleita pela Lei Maior, em especial no que toca o interrogatório policial.

Nesse tracejado, por força da norma extensiva prescrita no inciso $\mathrm{V}$ do artigo $6^{\circ}$ do Código de Processo Penal, em face da expressão "no que for aplicável” e do enquadramento legal conferido ao interrogatório judicial, devida é a análise de suas principais balizas constitucionais, não raro atacadas em razão da persistente incidência dos ultrapassados sistemas inquisitivo e acusatório, como se verifica em relação à obrigatoriedade de assistência do investigado por advogado e no toante ao direito ao silêncio do investigado.

Em relação à obrigatoriedade de assistência por advogado, o artigo 133 da Constituição Federal enuncia de maneira peremptória que o advogado é indispensável à administração da justiça, sendo sua presença e participação em todas as fases e atos que envolvam seu representado não só relevantes, mas obrigatórias. (BRASIL, 1988).

Esta prerrogativa não se restringe apenas aos atos ocorridos perante a autoridade judiciária, mas também, no que toca à seara criminal, à autoridade policial, sobretudo com suporte nos incisos LV e LXIII do artigo $5^{\circ}$ da Constituição Federal, no artigo $8^{\circ}$, inciso $6^{\circ}$, da Convenção Americana de Direitos Humanos, no artigo $7^{\circ}$, inciso III, da Lei n. 8.906/94, e no artigo 41, inciso IX, da Lei n. 7.210/84. Não por outra razão, adverte Marta Saad (2007, p. 6):

É preciso, de fato, garantir a defesa efetiva quando esta realmente importa, assegurando-se o exercício deste direito no curso do inquérito policial: não só a autodefesa, insuficiente em razão do próprio comprometimento emocional e do desconhecimento técnico do acusado; este deve contar com a assistência de advogado, legalmente habilitado, zeloso e competente, na real defesa dos interesses de sua liberdade.

Não é plausível considerar que o indiciado ou o suspeito trafegue por todo o procedimento administrativo ocorrido em sede policial sem que disponha da devida orientação de advogado. Afinal, ainda que seja dado à prática delitiva, ou mesmo tenha conhecimento técnico das letras jurídicas, nesta quadra, está o suspeito com ânimo fragilizado, em desventurada condição de debilidade, visto que o aparato estatal sobre ele depõe suas ferramentas e o seu zelo, não raro, de caráter inquisitório. Para Lopes Júnior (2003a, p. 382):

No momento do crime, a vítima é o débil e, por isso, recebe a tutela penal. Contudo, no processo penal opera-se uma importante modificação: o mais débil passa a ser o acusado, o que frente ao poder de acusar do Estado, sofre a violência institucionalizada do processo e, posteriormente, da pena. O sujeito passivo do processo, aponta Guarnieri, passa a ser o protagonista, porque ele é o eixo em torno do qual giram todos os atos do processo.

Este estado de debilidade não é exclusividade do acusado inserido na marcha processual, antes, alcança também o indiciado em sede administrativa, vez que nesta condição fica sujeito a medidas diversas, tais como prisões cautelares, arresto, sequestro, buscas e apreensões, etc. Ora, 
seria minimamente incoerente supor que o potencialmente afligido não pudesse dispor do amparo técnico de um advogado para enfrentar tais reveses.

Entretanto, é justamente isso que costuma ocorrer nas delegacias de polícia espalhadas por todo o país, onde a presença e participação do advogado para a realização dos atos que compõem o inquérito policial é considerada de somenos importância, inclusive no que toca à feitura do interrogatório policial.

Nesse âmbito, com considerável suporte doutrinário, desconsidera-se o direito do indiciado à entrevista pessoal e reservada com seu defensor, não obstante os claros termos do $\S 5^{\circ}$ do artigo 185 do Código de Processo Penal, que deve ser combinado com o artigo $6^{\circ}$, inciso V, do mesmo diploma legal. Postura que implica em gravames por vezes irreversíveis para o acusado, pois, graças ao cotejo judicial consagrado pelo artigo 155 do Código de Processo Penal, o magistrado poderá avaliar as declarações reduzidas a termo no interrogatório policial como elementos informativos probatórios, aptos a supostamente agregar valor ao material reproduzido em juízo posteriormente. Atenta a esta realidade, postula Marta Saad (2006, p. 6):

Em razão de ser o inquérito carregado de atos definitivos, que não mais se repetem no curso da persecução penal [...], exibe importância que reclama, em benefício do acusado, em favor de sua liberdade e da própria sociedade, o exercício do direito de defesa desde o seu início, com a nomeação, inclusive, de defensor dativo ao acusado impossibilitado de fazê-lo.

Não é preciso alto grau de abstração para verificar que esta prática não se coaduna com a proposta epistemológica da Constituição Federal, que enaltece e disponibiliza o contraditório e a ampla defesa para os acusados em geral, seja na esfera judicial, seja no âmbito administrativo artigo $5^{\circ}$, LV (BRASIL, 1988).

Por esta razão, segundo Fernandes (2004, p. 6), torna-se necessário declarar "nulos e ilícitos todos os interrogatórios em fase policial sem a presença do advogado e sem consulta prévia deste pelo investigado, devendo ser desentranhados dos autos, ou inutilizados, a pedido da defesa". Arremata o autor: "é que tal modificação também ocorreu no inquérito, e assim é obrigatória a presença do advogado para o depoimento na polícia. Não ocorrendo haverá nulidade nas declarações, sendo a prova ilícita e devendo ser desentranhada dos autos".

Torna-se necessário fazer prevalecer de forma efetiva a proposta epistemológica constitucional, vez que a sociedade, o indiciado e o próprio Estado, conforme preleciona Aury Lopes Júnior (2003a, p. 391), só tendem a se beneficiar do arquétipo de princípios e preceitos instituídos pela Constituição Federal:

A ausência de intervenção da defesa torna impossível o controle das discussões e possibilita os erros de interpretação ou omissões, que a presença do defensor haveria evitado. Frente a incerteza que emerge da ignorância do órgão encarregado da investigação, muitas provas são produzidas inutilmente, quando poderiam ter sido evitadas ao conhecer determinadas testemunhas ou outros elementos que 
dispõem a defesa.

Das instituições públicas e dos agentes que lhes conferem real existência, almeja-se evolução e consequente maturidade, condição que tende a lhes fazer reconhecer suas limitações, bem como a necessidade de uma atuação conjunta e verdadeiramente democrática em prol do interesse público e do bem comum.

No tocante ao direito ao silêncio do investigado, com o advento da Constituição Federal (BRASIL, 1988), que assegurou ao preso e ao acusado em geral o direito de permanecerem calados quando conduzido perante a autoridade policial e judiciária (artigo $5^{\circ}$, LXIII), maiores problemas não surgiram para materialização de tal garantia. Tanto que, de pronto, frações do Código de Processo Penal que permitiam que o magistrado formasse seu convencimento levando em consideração o silêncio do interrogado (artigo 198), foram tacitamente revogadas, postulado que conta com o substancial reforço do artigo $8^{\circ}, \S 2^{\circ}$, alínea "g", da Convenção Americana de Direitos Humanos.

Contudo, ainda assim algumas nuances do instituto merecem ser analisadas de forma mais pormenorizada, uma vez que o estigma inquisitório ou o maculado sistema acusatório ainda permanece impedindo o exercício pleno das faculdades conferidas pelo sistema democrático constitucional.

Assim, inicialmente, é preciso demarcar a partir de que momento o suposto investigado deve ser cientificado a respeito da imputação a ele impingida, ainda que potencialmente. De modo que, declarações apresentadas em contexto extraprocedimental, ao menos no entender do interrogado, não sejam a ele atribuídas em decorrência de ardil investigativo.

Frente à identificação da problemática, prelecionam Aury Lopes Júnior e Roberta Coelho Klein (2013, p. 5-6):

[...] para que o sujeito passivo exerça seu direito de defesa, deve ter conhecimento de seu indiciamento, sob pena de imaginar estar prestando depoimento na condição de testemunha, quando na verdade figura na condição de indiciado. No mínimo, o estado de "suspeito", estágio pré-indiciamento, deveria ser informado, pois diante desta informação poderá utilizar o direito de silêncio, com base no princípio nemo tenetur se detegere, bem como se fazer acompanhar de um advogado.

Neste quadro de velada inquisição, não raro a imprensa se vale do indiciado para impulsionar seus índices de audiência. O resultado é a redução do sujeito à condição de objeto a ser leiloado pelos grupos jornalísticos, bem como o desbaratamento dos institutos que compõem a instrução preliminar, inclusive, o interrogatório policial. De acordo com Moura (1994, p. 141):

A questão deve ser encarada com seriedade, haja vista que, com certa frequência, o preso é submetido a verdadeiro "interrogatório" pela imprensa, mormente a falada e televisada, antes ou após a lavratura do flagrante e sem o conhecimento 
de seu direito constitucional, e tal peça, embora informal, acaba por ser utilizada judicialmente contra o "interrogado". Por vezes, ainda, a conversa pessoal entre indiciados presos e autoridades policiais, antes ou depois do interrogatório, é gravada sem o conhecimento daqueles, e, de igual modo, utilizada, judicialmente, em prejuízo da defesa. Cremos que, desde o momento da prisão, deve ser conferido e assegurado ao indivíduo o direito ao silêncio, e nada do que vier a dizer, sem que seja alertado do seu direito constitucional, poderá ser utilizado contra si. [...] a Lei Maior preocupou-se com a pessoa capturada, assegurando a esta, mesmo fora e antes do interrogatório, o direito ao silêncio.

Fato é que o exercício do direito ao silêncio do indiciado precisa ocorrer nos devidos moldes constitucionais. Qualquer desvirtuamento da garantia é prejudicial, sejam as declarações instigadas pela imprensa e por investigadores de polícia em âmbito extraprocedimental, seja o próprio exercício do silêncio, quando, estrategicamente, com a devida orientação de advogado, se optaria pela verbalização dos fatos. Para Fernandes (2004, p. 6-7):

Será, igualmente, ilegal o depoimento se o investigado tiver optado pela garantia constitucional de permanecer calado, sem a consulta prévia que a lei garante. Isto porque o depoimento pode ser elemento de defesa e o investigado pode estar perdendo uma oportunidade de fazer prova em seu benefício. É público que muitas vezes os policiais incentivam "a garantia do silêncio", ou resolvem travestir-se de conselheiros dos investigados.

Ressalte-se que, numa perspectiva constitucional, o interrogatório policial detém finalidade estritamente defensiva, não devendo ser desvirtuado para construção de conjunto probatório. $\mathrm{O}$ instituto não serve a este desiderato.

Com efeito, "o direito em tela integra a autodefesa do incriminado, consubstanciada no direito de audiência: tem ele o direito de fornecer subsídios à defesa técnica, mas, como é dispensável e renunciável, pode, também, como forma de defesa, preferir o silêncio" (MOURA, 1994, p. 137).

$\mathrm{Na}$ linha do princípio nemo tenetur se detegere, materializado pelo direito ao silêncio presente no interrogatório, é possível afirmar que o interrogatório policial é elemento informativo defensivo, não imputando ao indiciado qualquer dever de produzir ou estar sujeito à produção de provas. Afinal, goza este de presumida condição de inocência. Segundo Lopes Júnior (2015, p. 43):

A partir do momento em que o imputado é presumidamente inocente, não lhe incumbe provar absolutamente nada. Existe uma presunção que deve ser destruída pelo acusador. Sem que o réu (e muito menos o juiz) tenha qualquer dever de contribuir nessa desconstrução (direito de silêncio - nemo tenetur se detegere). Ferrajoli esclarece que a acusação tem a carga de descobrir hipóteses e provas, e a defesa tem o direito (não dever) de contradizer com contra-hipóteses e contraprovas.

A adoção de sistemática processual que se coadune com a proposta constitucional garantirá 
que equívocos teóricos e práticos sejam afastados, preservando-se com isso os direitos fundamentais do investigado ou indiciado.

\subsection{Incoerência entre a natureza jurídica do interrogatório policial e a formação da convic- ção do magistrado a partir do artigo 155 do Código de Processo Penal}

Consciente da impossibilidade de se declarar abertamente a existência de um sistema híbrido, parcela da comunidade jurídica enuncia a vigência de uma sistemática processual acusatória. Contudo, tal postura não se coaduna com a realidade.

Na sistemática processual penal a que estão sujeitos os atores processuais e o Estado-juiz, o magistrado assume primazia na gestão probatória, bem como detém poderes suficientemente elásticos para se apropriar, ainda que em suposto caráter subsidiário, do conjunto probatório produzido perante a autoridade policial.

Tal proceder, embora travestido de suporte epistemológico acusatório, em realidade sustenta o arquétipo inquisitivo como princípio unificador do sistema. As consequências não poderiam ser mais nefastas. Para Saad (2006, p. 6):

[...] muitos dos meios de prova, colhidos no curso do inquérito, sem qualquer participação da defesa, são utilizados para sustentar futuras sentenças condenatórias. Ainda, no curso do inquérito, decretam-se medidas diversas, tais como prisões cautelares, arresto e sequestro, buscas e apreensões, tudo mantendo o envolvido alheio, como se estranho fosse ao procedimento.

Com suporte neste pseudossistema acusatório, abriga-se no Código de Processo Penal preceito que viabiliza a somatória das provas produzidas em juízo, sob o crivo do contraditório e da ampla defesa, com os elementos informativos coligidos aos autos do inquérito policial. Sem que se observe, nesta prática formalizada, o contraditório e a ampla defesa para a formação do convencimento do magistrado (artigo 155 do CPP). Consoante Lopes Júnior (2008, p. 9-10):

O art. 155 não teve coragem para romper com a tradição brasileira de confundir atos de prova com atos de investigação, com graves reflexos na eficácia probatória deles. A redação vai muito bem, até o ponto em que inseriram a palavra errada, no lugar errado. E uma palavra, faz muita diferença... Bastou incluir o "exclusivamente" para sepultar qualquer esperança de que os juízes parassem de condenar os réus com base nos atos do famigerado, inquisitório e superado inquérito policial. Seguiremos assistindo a sentenças que, negando a garantia de ser julgado a partir de atos de prova (realizados em pleno contraditório, por elementar), buscarão no inquérito policial (meros atos de investigação e sem legitimidade para tanto) os elementos (inquisitórios) necessários para condenação.

Apenas este ponto já seria o suficiente para desvirtuar o sistema que se propõe acusatório, mas há mais (LOPES JUNIOR, 2000, p. 85): a) as provas, em regra, não são reproduzidas em 
juízo, mas tão somente se confere uma nova roupagem aos elementos informativos produzidos perante a autoridade policial; b) ainda que as provas fossem efetivamente reproduzidas em juízo e os elementos informativos trazidos do inquérito policial fossem utilizados como mero referencial, o sistema ainda restaria burlado, uma vez que o produto da instrução preliminar serve apenas à fundamentação do processo ou não-processo, e não de suporte para o convencimento derradeiro do magistrado; c) como num efeito prejudicial circular, ainda que os elementos informativos servissem apenas para justificar o processo ou o não-processo, restariam descaracterizados frente à ausência do contraditório e da ampla defesa em sede policial; d) finalmente, a prova construída em juízo não deve ser reproduzida com base nas investigações policiais, mas efetivamente produzida. Por essa razão, concretizado o ajuizamento da ação penal, o inquérito policial não deve seguir apensado aos autos do processo.

É desta encruzilhada epistemológica que emerge o interrogatório policial desvirtuado desde o seu nascedouro, feito à força elemento informativo probatório, com seu aproveitamento até mesmo em juízo para a prolação da sentença penal condenatória.

Em razão do ataque à natureza do interrogatório policial, ou ainda numa perspectiva mais ampla do inquérito policial, o sistema democrático constitucional é desmantelado, dando margem a um exacerbado ativismo judicial. Para Lopes Júnior (2013, p. 5-6):

O sistema processual penal democrático impõe a máxima eficácia das garantias constitucionais e está calcado no "amor ao contraditório". É aquele que, partindo da Constituição, cria as condições de possibilidade para a máxima eficácia do sistema de garantias fundamentais, estando fundado no contraditório efetivo, para assegurar o tratamento igualitário entre as partes, permitir a ampla defesa, afastar o juiz-ator e o ativismo judicial para garantir a imparcialidade.

Não por outra razão, de forma enérgica, denuncia Rosemiro Pereira Leal (2001, p. 157):

Só admitindo que a lei formulada é muda, não objetiva, fatalmente ininteligível e obstativa de criação e realização de direitos, nada transmitindo em seu discurso léxico-gramatical e que, ao ser editada, tornar-se-ia coisa inerte, inexpressiva, caótica e inútil, é que seria possível dizer que o sentido da lei é o investigado e atribuído pelo intérprete-aplicador do direito. Isto, por certo, resultaria numa interpretação engendrada pela argumentação que, invés de "algo que vai longe da discricionariedade", seria, ao contrário, algo que iguala à mais desabrida autocracia interpretativa (personalismo hermenêutico). A constituição formal, com conquista histórica da lei democrática, é fonte objetiva de conteúdos jurídicos de vinculação originária do intérprete (interpretação conforme a constituição), como cláusula de vedação de busca de verdade absoluta pelo subjetivismo realista (poder social) do aplicador da norma (logus judicatorum).

Torna-se imperiosa uma militância democrática mais incisiva, de modo a evitar a perpetuação da sistemática processual inquisitória ou mesmo pseudoacusatória, possibilitando que 
venha a triunfar o sistema democrático constitucional estabelecido há mais três décadas no Brasil.

\subsection{Estatuto da Ordem dos Advogados do Brasil e reflexos no modelo democrático constitu- cional}

Segundo Aury Lopes Júnior (2013, p. 5-6), a controvérsia entre sistema inquisitório e acusatório, frente aos postulados constitucionais, está ultrapassada. Para o jurista, o sistema inquisitório seria integralmente inconstitucional; o misto, no mínimo, parcialmente inconstitucional; o acusatório, numa perspectiva que enfrente o crivo da Convenção Internacional dos Direitos Humanos, insuficiente.

O princípio democrático, alçado como baluarte da Constituição Federal, espraia-se por toda sistemática infraconstitucional, razão pela qual não se pode conceber uma realidade jurídica que minimize sua influência e seus efeitos.

Na visão de Aury Lopes Júnior (2013, p. 5-6), mesmo o sistema acusatório, em decorrência dos constantes embates a que se viu exposto com as linhas inquisitivas e mistas, restou fragilizado. Tal ocorrência abriu margem à análise dos institutos sob novo viés, de modo a potencializar a proposta constitucional democrática.

Vários são os pontos que indicam a incoerência entre a proposta constitucional e a sistemática ainda adotada pelo Código de Processo Penal. Mas, de todos estes, a gestão judicial da prova é premissa que provoca maior escândalo entre os que propõe adotar a linha epistemológica traçada pela Constituição Federal. Todavia, este quadro, ainda que de forma tímida, começa a mudar.

O interrogatório policial, realizado a partir dos parâmetros de uma sistemática inquisitiva, que valora o instituto como mero elemento probatório, sujeito a ulterior condição de prova a ser apreciada em juízo, deparou-se com novos fluxos democráticos, desde a entrada em vigor da Lei n. 13.245/16, que alterou o artigo $7^{\circ}$ da Lei n. 8.906/94 (Estatuto da Ordem dos Advogados do Brasil).

A partir dessa premissa legal, a presença do advogado no transcorrer do inquérito policial, e em especial durante a realização do interrogatório, consolidou-se como condição de validade do ato empreendido pela Polícia Judiciária, bem como abriu margem para que o material produzido, considerado pela lei como elemento probatório, receba o manejo não apenas da autoridade policial ou da autoridade judicial, mas igualmente da defesa. Esta, frente à concretização de atos investigatórios e probatórios, passa a ser dotada de poderosa ferramenta, ou seja, a possibilidade de apresentar não apenas quesitos, mas razões.

É sabido que a Constituição Federal de 1988 - artigo 5, LV (BRASIL, 1988) viabilizou o exercício do contraditório e da ampla defesa em sede policial, bem como exigiu que o indiciado, ainda que em potencial, dispusesse do acompanhamento de profissional com capacidade postulatória mesmo no âmbito administrativo. Contudo, ainda não se dispunha, de forma expressa, da possibilidade de apresentar razões perante a autoridade policial. Para Lopes Júnior (2003b, p. 
330):

No inquérito policial, a defesa técnica está limitada, pois limitada está a defesa como um todo. Ainda que o direito de defesa tenha expressa previsão constitucional, como explicamos anteriormente, na prática, a forma como é conduzido o inquérito policial quase não deixa espaço para a defesa técnica atuar no seu interior. Por isso, diz-se que a defesa técnica na fase pré-processual tem uma atuação essencialmente exógena, através do exercício do habeas corpus e do mandado de segurança, que, em última análise, corporificam o exercício do direito de defesa fora do inquérito policial. Dentro do inquérito basicamente só existe a possibilidade de solicitar diligências, nos estreitos limites do art. 14 do CPP.

Dentre as faculdades conferidas ao defensor que extrapolam os lindes exógenos e materializam o exercício endógeno de defesa, também é possível listar (SAAD, 2004, p. 271-271):

Ao praticar o exercício endógeno do direito de defesa, o acusado pode requerer diligências à autoridade policial, indicar-lhe testemunhas, formular quesitos e pedidos de esclarecimentos e complementação de laudos já apresentados, requerer a juntada de documentos e impugnar a autenticidade de documentos juntados aos autos, permanecer em silêncio durante o interrogatório e se recusar a participar da coleta e/ou produção de meios de prova que podem ser usados em seu desfavor, ser acompanhado de defensor legalmente habilitado, de sua confiança ou indicado pelo Estado quando não puder arcar com as custas, ser assistido por intérprete, em caso de não dominar o idioma ou não puder, de qualquer forma, compreendê-lo.

Nesta quadra, em acréscimo a essas possibilidades, por intermédio da apresentação de razões, pode o defensor, ainda que em tese, influenciar de maneira direta o destino da empreitada investigativa.

É certo que tal postura, essencialmente democrática, é desdobramento das garantias ao contraditório e à ampla defesa, constitucionalmente asseguradas para os acusados em geral. Ainda que, no que tange ao contraditório, conte-se com os devidos temperos técnicos, conforme afirmado por Saad (2004, p. 220):

De fato, no inquérito policial não se pode estabelecer contraditório, em sentido técnico, porque ainda não há parte acusadora, em sentido formal, ou seja, "não há parte e contraparte", nem tampouco há sujeito imparcial destinatário do resultado. Mas o delegado de polícia concentra em si poderes e funções que, depois, serão bipartidos entre o acusador - público ou privado - e o juiz.

De todo modo, frente à abertura da lei para que o defensor, mediante a apresentação de razões, maneje os elementos de convicção produzidos perante a autoridade policial, dentre os quais se inclui o interrogatório, verifica-se no inquérito a influência do modelo democrático proposto 
pela Constituição Federal.

Nestes moldes deve ser compreendida a persecução criminal, vez que a matéria objeto de investigação e ulteriores debates não se circunscreve aos estritos interesses de um indivíduo ou de seu defensor, mas de toda a sociedade e do próprio Estado, intrinsecamente interessados na materialização de um julgamento que preserve os direitos e garantias fundamentais, conferindo, por fim, a devida prestação jurisdicional.

Nesse contexto, a natureza jurídica do interrogatório realizado perante a autoridade policial deve ser considerada como estrito elemento defensivo, desatrelada de qualquer carga probatória preordenada ou intencional.

A respeito do valor probatório do interrogatório, afirma Lopes Júnior (2003b, p. 340):

Com relação ao valor probatório do interrogatório, propugnamos por um modelo garantista, em que o interrogatório é orientado pela presunção de inocência, visto assim como o principal meio de exercício da autodefesa e que tem, por isso, a função de dar materialmente vida ao contraditório, permitindo ao sujeito passivo refutar a imputação ou aduzir argumentos para justificar sua conduta. Especificamente na investigação preliminar, o interrogatório deve estar dirigido a verificar se existem ou não motivos suficientes para a abertura do processo criminal.

Eventuais elementos de convicção obtidos no interrogatório policial, à luz do modelo democrático, assumem caráter meramente endoprocedimental, apenas para verificar a existência dos requisitos necessários à abertura de processo penal. Logo, não há que se falar que o interrogatório policial possa assumir natureza probatória ou mista, vez que toda a marcha constitucional, inclusive com influência sobre a Lei n. 13.245/16, eleva o instituto à condição de pureza defensiva.

\section{CONCLUSÃO}

Após examinar o interrogatório policial brasileiro de forma pormenorizada, conclui-se que é este elemento informativo estritamente defensivo.

As feições probatórias incididas sobre o instituto ou as amálgamas probatório-defensivas decorrentes de um entendimento híbrido, à luz do modelo democrático proposto pela Constituição Federal, não devem ser toleradas. Servem tão só para desvirtuar a proposta constitucional.

O interrogatório policial é elemento que coopera para a construção do entendimento da autoridade policial, quando do eventual indiciamento, assim como confere subsídios ao órgão ministerial ao oferecer denúncia ou promover arquivamento. Entretanto, nem por isso o instituto deve ser considerado como elemento informativo probatório.

O inquérito policial não é o ambiente adequado para a produção de provas. Trata-se de instrução preliminar sumária, com finalidade estrita: colheita de subsídios que legitimem o processo ou o não-processo. O interrogatório policial, delineado neste contexto não pode ser confundido como prova a ser reproduzida em juízo. 
Nesta razão de ser, a natureza defensiva do instituto exige a presença, assistência e obrigatória influência de advogado para a realização do ato, assim como garante a todo o momento a entrevista pessoal e reservada deste com o seu cliente.

É também em decorrência da essência defensiva do inquérito policial, que todo aquele que é levado à presença da autoridade policial para ser interrogado dispõe da possibilidade de se manter silente, inclusive sendo previamente informado de seu direito, de modo a não ser fraudado por agentes públicos despreparados ou mal-intencionados, ou ainda por eventual inconveniência da imprensa.

O espírito que move a realização do inquérito policial, devidamente tipificado no arquétipo de princípios e preceitos da Constituição Federal, deve ser suficientemente hábil e dispor de força normativa para impedir que o convencimento do magistrado emitido no limiar da instrução criminal esteja de algum modo fundado nos elementos informativos colhidos em sede administrativa. Tal entendimento impõe a revisão do artigo 155 do Código de Processo Penal, bem como sugere o desentranhamento do inquérito policial, caso os autos avancem para a fase judicial da persecução.

Destaca-se o louvável avanço promovido pela Lei n. 13.245/16, que conferiu maiores subsídios à defesa endógena realizada durante a realização do inquérito policial.

Tem-se, em conclusão, que restou demonstrada a hipótese inicial, no sentido de que o interrogatório policial possui natureza jurídica de elemento defensivo, à luz do modelo constitucional democrático nacional, o que possibilita o respeito aos princípios constitucionais que regem a matéria e a preservação dos direitos fundamentais da pessoa investigada criminalmente.

\section{REFERÊNCIAS}

BARBOSA, Ruchester Marreiros. Lei ${ }^{\circ} 13.245 / 2016$ exige mais do que o advogado na investigação criminal. Revista Síntese de Direito Penal e Processual Penal, Porto Alegre, RS, v. 16, n. 96, p. 22-37, fev./mar. 2016.

BRASIL. [Constituição (1988)]. Constituição da República Federativa do Brasil de 1988. Brasília: Centro Gráfico do Senado Federal, 1988.

COUTINHO, Jacinto Nelson de Miranda. Sistema acusatório: cada parte no lugar constitucionalmente demarcado. Revista de informação legislativa - RIL, Brasília, DF, v. 46, n. 183, p. 103-115, jul./set. 2009.

FERNANDES, Fernando Augusto Henriques. Interrogatório contraditório no inquérito policial. Boletim IBCCRIM, São Paulo, SP, v. 12, n. 138, p. 6-7, maio 2004.

LEAL, Rosemiro Pereira. Processo e hermenêutica constitucional a partir do estado de direito democrático. Revista Jurídica da Universidade de Franca, Franca, SP, v. 4, n. 6, p. 152-164, maio 2001.

LOPES JÚNIOR, Aury. (Re)pensando os sistemas processuais em democracia: a estafa do 
tradicional problema inquisitório x acusatório. Boletim IBCCRIM, São Paulo, SP, v. 21, n. 251, p. 5-6, out. 2013.

LOPES JÚNIOR, Aury. A crise do inquérito policial: breve análise dos sistemas de investigação preliminar no processo penal. Revista Ibero-Americana de Ciências Penais, Porto Alegre, RS, v. 1, p. 57-86, maio/ago. 2000.

LOPES JÚNIOR, Aury. Bom para que(m)? Boletim IBCCRIM, São Paulo, SP, v. 16, n. 188, p. 9-10, jul. 2008.

LOPES JÚNIOR, Aury. Direito de defesa e acesso do advogado aos atos do inquérito policial: uma (des)construção jurisprudencial [Jurisprudência comentada]. Revista Brasileira de Ciências Criminais, São Paulo, SP, v. 11, n. 43, p. 378-396, abr./jun. 2003a.

LOPES JÚNIOR, Aury. Réu não deve ser obrigado a provar causa de exclusão da ilicitude.

Revista Magister de Direito Penal e Processual Penal, Porto Alegre, RS, v. 12, n. 67, p. 43-47, ago./set. 2015.

LOPES JÚNIOR, Aury. Sistemas de investigação preliminar no processo penal. 2. ed. Rio de Janeiro: Lumen Juris, 2003b.

LOPES JÚNIOR, Aury; KLEIN, Roberta Coelho. O indiciamento e a Lei 12.830/2013: um avanço, mas não o suficiente. Boletim IBCCRIM, São Paulo, SP, v. 21, n. 249, p. 5-6, ago. 2013.

MOURA, Maria Thereza Rocha de Assis. Direito ao silêncio no interrogatório. Revista Brasileira de Ciências Criminais, São Paulo, SP, v. 2, n. 6, p. 133-147, abr./jun. 1994.

SAAD, Marta. A defesa técnica dos presos em flagrante delito. Boletim IBCCRIM, São Paulo, SP, v. 14, n. 173, p. 6, abr. 2007.

SAAD, Marta. Exercício do direito de defesa no inquérito policial. Boletim IBCCRIM, São Paulo, SP, v. 14, n. 166, p. 6, set. 2006.

SAAD, Marta. O direito de defesa no inquérito policial. São Paulo: Revista dos Tribunais, 2004.

Como citar: REMEDIO, José Antonio; CARDOSO, Fernando Cerqueira. Interrogatório policial: Natureza jurídica à luz do modelo constitucional democrático brasileiro. Revista do Direito Público, Londrina, v. 16, n. 1, p. 48-69, abr. 2021. DOI: 10.5433/24157-108104-1.2021v16n1p. 48. ISSN: $1980-511 \mathrm{X}$

Recebido em: 06/01/2019

Aprovado em: 22/04/2019 